\title{
COMMENTS
}

\section{Attorney's Fees in Damage Actions Under the Civil Rights Attorney's Fees Awards Act of 1976}

In Alyeska Pipeline Service Co. v. Wilderness Society, ${ }^{1}$ the Supreme Court reaffirmed the so-called "American Rule" against awarding attorney's fees to prevailing parties in cases not falling into three well-recognized exceptions. ${ }^{2}$ Specifically, the Court disapproved a line of recent lower court cases creating another exception-referred to as the "private attorney general" theory-whereby some plaintiffs were thought to merit awards of attorney's fees because they were advancing the public interest. ${ }^{3}$ Several of the lower court cases ${ }^{4}$ were brought under the Reconstruction-era Civil Rights Acts. ${ }^{5}$ Although these Acts are silent regarding the award of fees, the lower courts permitted their recovery: since the later Civil Rights Acts permit the award of fees, ${ }^{6}$ it

1421 U.S. 240 (1975).

2 See id. at 257-59. The first exception involves the bad faith of the opposing party. See F.D. Rich Co. v. United States ex rel. Indus. Lumber Co., 417 U.S. 116, 129 (1974); Vaughan v. Atkinson, 369 U.S. 527, 530-31 (1962); Universal Oil Prods. Co. v. Root Ref. Co., 328 U.S. 575, 580 (1946); Guardian Trust Co. v. Kansas C. S. Ry., 28 F.2d 233, 246 (8th Cir. 1928), rev'd on other grounds, 281 U.S. 1 (1930); 6 J. Moore, Federal Practice II 54.77[2], at 1709-12 (2d ed. 1976). The second is invoked when a common fund benefiting persons other than the prevailing plaintiff is created as a result of the lawsuit. See Hall v. Cole, 412 U.S. 1, 14 (1973); Mills v. Electric Auto-Lite Co., 396 U.S. 375, 389-97 (1970); 6 J. Moore, supra, If 54.77[2], at 1705-08. Finally, there is an exception permitting assessment of the plaintiff's attorney's fees as part of the civil-contempt fine levied against a defendant who willfully disobeys a court order. See Fleischmann Distilling Corp. v. Maier Brewing Co., 386 U.S. 714, 718 (1967); Toledo Scale Co. v. Computing Scale Co., 261 U.S. 399, 426-28 (1923).

${ }^{3} 421$ U.S. at 270 n.46.

4 Fowler v. Schwarzwalder, 498 F.2d 143 (8th Cir. 1974); Hoitt v. Vitek, 495 F.2d 219 (1st Cir. 1974); Cornist v. Richland Parish School Bd., 495 F.2d 189 (5th Cir. 1974); Cooper v. Allen, 467 F.2d 836 (5th Cir. 1972); Knight v. Auciello, 453 F.2d 852 (1st Cir. 1972); Sims v. Amos, 340 F. Supp. 691 (M.D. Ala.), aff'd mem., 409 U.S. 942 (1972). See also Alyeska, 421 U.S. at 264.

s 42 U.S.C. $\S \S 1981-1983,1985-1986$ (1976).

6 E.g., Emergency School Aid Act of 1972, § 718, 20 U.S.C. § 1617 (1976) (repealed 1978); Voting Rights Act Amendments of 1975, $\S 402,42$ U.S.C. $\S 1973(\mathrm{e})$ (1976); Civil Rights Act of 1964, § 204(b), 42 U.S.C. $\$ 2000 \mathrm{a}-3(\mathrm{~b})$ (1976); id. $\S 706(\mathrm{k}), 42$ U.S.C. $\S 2000 \mathrm{e}-$ 
was thought equitable-and consistent-that such an award be permitted under the earlier Acts. The Alyeska Court rejected this reasoning, holding that for the judiciary to create such an exception to the American Rule would be to "invade the legislature's province."7

Congress reacted swiftly to Alyeska by enacting the Civil Rights Attorney's Fees Awards Act of 1976..$^{8}$ The Act amended section 1988 of Title 42 to allow the award of attorney's fees to prevailing parties in suits to enforce the early civil rights statutes. ${ }^{\circ}$

5(k) (1976); Fair Housing Act of 1968, § 812(c), 42 U.S.C. $§ 3612(c)$ (1976).

Civil rights is not the only area in which federal statutes provide for the award of attorney's fees. For a list of such statutes, see Council for Public Interest Law, Balancing the SCALES of JUSTICE app. E (1976). There are a number of state statutes containing such authorization as well. A table of these statutes, listed alphabetically by state and containing summaries of the matters addressed by the legislation, as well as indications of which parties may recover attorney's fees and whether the awards are discretionary or mandatory, is appended to J. Lorenz \& B. Hunter, Financing Private Enforcement Through Statutes Authorizing Awards of Attorneys' Fees (1979) (unpublished study for Council for Public Interest Law) (on file with The University of Chicago Law Review).

7421 U.S. at 271 . See id. at $260-64,269$.

s Pub. L. No. 94-559, 90 Stat. 2641 (1976) (codified at 42 U.S.C. § 1988 (1976)).

The response of Congress to Alyeska parallels the almost uniform expression of apprehension about the future of private civil rights enforcement found in academic commentary on the decision. See, e.g., Special Project-Recent Developments in Attorneys' Fees, 29 Vand. L. Rev. 685 (1976); Comment, Alyeska Pipeline Turns Off the Tap: Can Public Interest Law Survive?, 71 Nw. U.L. Rev. 239 (1976); Comment, After Alyeska: Will Public Interest Litigation Survive?, 16 Santa Clara L. Rev. 267 (1976); 51 Wash. L. Rev. 1047 (1976). But see Walker, Court Awarded Attorney's Fees Under the Private Attorney General Concept: A Defense Perspective, 23 U. Kan. L. Rev. 653 (1975).

The Act amended section 1988 to read in pertinent part:

In any action or proceeding to enforce a provision of sections $1981,1982,1983,1985$, and 1986 of this title, title IX of Public Law $92-318 \ldots$, or in any civil action or proceedings, by or on behalf of the United States of America, to enforce, or charging a violation of, a provision of the United States Internal Revenue Code, or title VI of the Civil Rights Act of 1964 . . . the court, in its discretion, may allow the prevailing party, other than the United States, a reasonable attorney's fee as part of the costs. 42 U.S.C. $\$ 1988$ (1976).

For a detailed summary of the progress of the Act through Congress, see Malson, In Response to Alyeska-The Civil Rights Attorney's Fees Awards Act of 1976, 21 ST. Louls U. L.J. 430, 432-36 (1977).

The bill reported out of the Senate Judiciary Committee, S. 2278, 94th Cong., 2d Sess. (1976), was passed with two substantive amendments, neither of which bears on the issue discussed in this comment. The first, the provision including Title IX of Pub. L. No. 92-318 (the Emergency Schools Aid Act, 20 U.S.C. \$§ 1601-1619 (1976) (repealed 1978)), was offered by Representative Holtzman of the House Judiciary Committee and incorporated into H.R. 15,460, 94th Cong., 2d Sess. (1976), the bill reported out of that committee. The Holtzman amendment was introduced on the floor of the Senate by Senator Kennedy during the consideration of S. 2278. 122 CoNG. REc. 31471 (1976).

The second amendment, concerning provisions of the Internal Revenue Code, was called up by Senator Allen eight days later and adopted unanimously by the Senate. Id. at 
The Act provides that the award is subject to the district court's discretion, but it gives no textual guidance as to how that discretion is to be exercised. Nonetheless, the courts are in general agreement ${ }^{10}$ that the standard of discretion under section 1988 for awarding fees to successful plaintiffs in injunctive cases is the same as that governing similar attorney's fees provisions under modern civil rights statutes:11 a prevailing plaintiff "should ordinarily recover an attorney's fee unless special circumstances would render such an award unjust."12

The courts, however, are in disagreement over the proper scope of judicial discretion for awarding fees in damage actions under section 1988. Some courts have erected a separate standard

33311. This amendment raises interesting questions, not relevant to this comment, concerning the circumstances under which the Act authorizes awards of attorney's fees to taxpayerdefendants unsuccessfully sued by the United States. See generally Comment, The Civil Rights Attorney's Fees Awards Act of 1976, Key Buick, and Aparacor: The Availability of Fee Awards to Prevailing Taxpayers and Standards for the Exercise of Judicial Discretion, 31 TAx Law. 855 (1978); Comment, Court Awarded Attorneys' Fees in Tax Litigation: 42 U.S.C. $\S 1988,126$ U. PA. L. REv. 1368 (1977).

With respect to tax litigation, of course, the amendment is explicit that taxpayers can obtain fees from the United States. As to civil rights, however, the Act neither affirms nor denies that fees may be assessed in suits against the Federal Government. So far, the courts of appeals have held that the Act does not contain a waiver of federal sovereign immunity in civil rights cases that is sufficiently unequivocal as to defeat the immunity provisions of 28 U.S.C. $\& 2412$ (1976). E.g., NAACP v. Civiletti, 609 F.2d 514 (D.C. Cir. 1979). Chief Judge Wright, dissenting in Civiletti, expressed the view that refusing to apply section 1988 to federal defendants defeats in large measure the general congressional purposes behind the Act. Id. at 531 .

10 Northcross v. Board of Educ. (Northcross II), 611 F.2d 624 (6th Cir. 1979); Konczak v. Tyrrell, 603 F.2d 13 (7th Cir. 1979), cert. denied, 100 S. Ct. 668 (1980); Dawson v. Pastrick, 600 F.2d 70 (7th Cir. 1979); Criterion Club v. Board of Comm'rs, 594 F.2d 118 (5th Cir. 1979) (per curiam); Skehan v. Board of Trustees, 590 F.2d 470 (3d Cir. 1978), cert. denied, 100 S. Ct. 61 (1979); Davis v. Murphy, 587 F.2d 362 (7th Cir. 1978); Monroe v. County Bd. of Educ., 583 F.2d 263 (6th Cir. 1978); Nadeau v. Helgemoe, 581 F.2d 275 (1st Cir. 1978); Morrow v. Dillard, 580 F.2d 1284 (5th Cir. 1978); Sargeant v. Sharp, 579 F.2d 645 (1st Cir. 1978); Mid-Hudson Legal Servs., Inc. v. G \& U, Inc., 578 F.2d 34 (2d Cir. 1978); Perez v. Rodriguez Bou, 575 F.2d 21 (1st Cir. 1978); Green v. Ten Eyck, 572 F.2d 1233 (8th Cir. 1978); Wharton v. Knefel, 562 F.2d 550 (8th Cir. 1977); Seals v. Quarterly County Court, 562 F.2d 390 (6th Cir. 1977); Brown v. Culpepper, 559 F.2d 274 (5th Cir. 1977); Fagot v. Ciravola, 445 F. Supp. 342 (E.D. La. 1978); W. v. Louisiana, 441 F. Supp. 1121 (E.D. La. 1977).

11 See note 6 supra.

12 Newman v. Pig̈gie Park Enterprises, Inc., 390 U.S. 400, 402 (1968) (per curiam) (Title II, 42 U.S.C. \& 2000a-3(b) (1976)). Accord, Christiansburg Garment Co. v. EEOC, 434 U.S. 412, 416-17 (1978) (dictum) (Title VII, 42 U.S.C. $\$ 2000 \mathrm{e}-5(\mathrm{k})$ (1976)); Albemarle Paper Co. v. Moody, 422 U.S. 405, 414 (1975) (dictum) (same); Northcross v. Board of Educ., 412 U.S. 427, 428 (1973) (per curiam) (Emergency School Aid Act, 20 U.S.C. $§ 1617$ (1976) (repealed 1978)). 
for damage actions, ${ }^{13}$ while others have continued to apply the "special circumstances" standard." This comment will examine these decisions and the legislative history and purpose of the Act in an attempt to define the proper scope of discretion in damage actions. The comment will conclude that the separate standard for damage actions put forth by some courts is improper because it is not in accord with Congress's intent to use attorney's fees to open the courts to civil rights plaintiffs and to enhance the deterrent effect of civil rights judgments. Congress intended that the same standard-recovery of fees for the successful plaintiff except in extraordinary circumstances-should apply to injunctive and damage actions alike.

\section{The "Bright Prospects" Standard for Damage Actions}

The courts and commentators ${ }^{15}$ are in agreement that, at least with regard to actions seeking only injunctive relief, a prevailing plaintiff should ordinarily recover attorney's fees under section 1988 unless special circumstances ${ }^{16}$ would render such an award unjust. This has been called the Newman-Northcross standard, af-

${ }^{13}$ Buxton v. Patel, 595 F.2d 1182 (9th Cir. 1979); Zarcone v. Perry, 581 F.2d 1039 (2d Cir. 1978), cert. denied, 439 U.S. 1072 (1979).

14 Sargeant v. Sharp, 579 F.2d 645 (1st Cir. 1978).

${ }^{15}$ Cases cited note 10 supra; Derfner, One Giant Step: The Civil Rights Attorney's Fees Awards Act of 1976, 21 ST. Lours U. L.J. 441 (1977); Larson, The Civil Rights Attorney's Fees Awards Act of 1976, 10 Clearinghouse Rev. 778 (1977); Lipson, Beyond Alyeska-Judicial Response to the Civil Rights Attorneys' Fees Act, 22 ST. Lours U. L.J. 243 (1978); Malson, supra note 9; Note, The Enforceability and Proper Implementation of $\S$ 1983 and the Attorney's Fees Awards Act in State Courts, 20 ArIz. L. REv. 743 (1978); Comment, The Civil Rights Attorney's Fees Awards Act of 1976, 52 Sr. JoHN's L. REv. 562 (1978); Comment, The Civil Rights Attorneys' Fees Awards Act of 1976, 34 Wash. \& LeE L. REv. 205 (1977).

16 While the legislative history of the Act gives no specific indication as to what constitutes "special circumstances," several recent decisions give the term particular meaning. See, e.g., Chastang v. Flynn \& Emrich Co., 541 F.2d 1040, 1044-45 (4th Cir. 1976) (hardship would be visited upon innocent third parties by levying counsel fees against a defendant pension fund in a case in which other defendants constituted a source of fees for the plaintiff); Consumers Union v. American Bar Ass'n, 470 F. Supp. 1055, 1062-63 (E.D. Va. 1979) (three-judge court) (fees levied against only one group of defendants in a multiparty suit because others only technically liable and real responsibility for the wrong lay with the former); Bacica v. Board of Educ., 451 F. Supp. 882, 889 (W.D. Pa. 1978) (trial court "severely handicapped" in case because of "failure of the plaintiff's counsel to marshal the evidence and make a clear presentation of controlling facts, despite several requests from the Court").

Additionally, courts possess discretion with regard to fee awards in some circumstances other than those relevant to this comment. See note 95 infra. 
ter the two leading Supreme Court cases interpreting identical attorney's fees provisions in similar civil rights statutes. ${ }^{17}$

The First Circuit, in Sargeant $v$. Sharp, ${ }^{18}$ held the NewmanNorthcross standard applicable under section 1988 to a damage action. The action involved was, as the court noted, "atypical of civil rights actions"19 since it had been brought on a contingent-fee basis. Although the court hinted that the nature of the relief sought-damages-might be relevant in deciding whether or not the case fit the "special circumstances" exception of NewmanNorthcross, it remained an inconsequential factor in light of Congress's overriding purpose to encourage private enforcement of the civil rights statutes. ${ }^{20}$ With respect to the complications the fee arrangement might present, the court observed that the trial court could fashion its award of fees to prevent overcompensation of counsel and assure justice to the plaintiff. ${ }^{21}$

Two other courts have taken a sharply different view of damage actions under section 1988. In Zarcone v. Perry, ${ }^{22}$ the Second Circuit refused to follow the Newman-Northcross standard, applying instead a separate standard for awarding attorney's fees. The plaintiff Zarcone operated a food vending truck which stopped at the courthouse where the defendant Perry sat as a judge. On the evening of the occurrence of the events leading to the suit, the defendant ordered a deputy sheriff to obtain some coffee from Zarcone. Judge Perry, upon finding the coffee unsatisfactory, dispatched the deputy sheriff and other law officers to bring Zarcone before him in handcuffs. Zarcone was led to the judge through the crowded courthouse, subjected to a tirade about the quality of the coffee, and threatened with the loss of his livelihood. Another similar session was conducted an hour or so later. ${ }^{23}$

Zarcone brought suit against Judge Perry, alleging that the incident had injured him mentally and physically, caused marital difficulties, and prevented him from working. The jury awarded

17 Northcross v. Board of Educ., 412 U.S. 427 (1973) (per curiam); Newman v. Piggie Park Enterprises, Inc., 390 U.S. 400 (1968) (per curiam).

18579 F.2d 645 (1st Cir. 1978).

19 Id. at 648.

${ }^{20} I d$.

${ }^{21}$ Id. Cf. Dennis v. Chang, 611 F.2d 1302 (9th Cir. 1980) (assuring that award went to legal aid agency that provided free counsel).

${ }^{22} 581$ F.2d 1039 (2d Cir. 1978), cert. denied, 439 U.S. 1072 (1979).

${ }^{23}$ The facts of the case are recounted in detail in a prior appeal, Zarcone v. Perry, 572 F.2d 52, 53-54 (2d Cir. 1978). 
him $\$ 80,000$ in compensatory damages and $\$ 61,000$ in punitive damages. ${ }^{24}$ Zarcone, who had litigated under a contingent-fee agreement with his counsel, moved under the Act to amend the bill of costs to include counsel fees of $\$ 53,917.50$.

The district court denied Zarcone's motion for attorney's fees. ${ }^{25}$ "It is only when plaintiffs advance the public interest by bringing the action," the court noted, "that an award of attorneys' fees [under the Act] is proper." Zarcone's suit was characterized by the court as one "solely for damages" and "basically a tort action ... couched in the language of a violation of the constitutional right to due process."27 Hence, the suit vindicated the public interest at best in an attenuated way, "to the degree that every successful plaintiff in a personal injury action vindicates the public's right not to be injured through the negligent conduct of an operator of a motor vehicle, a doctor, or a lawyer."28

Although the Second Circuit affirmed on appeal, it criticized the district court's reasoning. "Congress," said the court, "was concerned with enforcement not only of the civil rights of the public at large and of identifiable groups but also with the rights of individual plaintiffs." $2 \theta$ Thus, the district court had erred in concluding that fees may be awarded under the Act only in cases conferring benefits on persons other than the plaintiff through injunctive or class relief. ${ }^{30}$

24 Of the punitive award, $\$ 1,000$ was levied against the deputy sheriff who had carried out the defendant judge's orders. 581 F.2d at 1040. Judge Perry was removed from the bench because of the incident. In re Perry, 53 A.D.2d 882, 385 N.Y.S.2d 589, appeal dismissed, 40 N.Y.2d 1079, 360 N.E.2d 964, 392 N.Y.S.2d 1029 (1976).

${ }^{23}$ Zarcone v. Perry, 438 F. Supp. 788 (E.D.N.Y. 1977).

${ }^{26}$ Id. at 791.

27 Id. at 790 .

${ }^{28} \mathrm{Id}$. at $790-91$.

28581 F.2d at 1042.

${ }^{30}$ Id. The appellate court's disagreement with the district court was more a matter of approach than of result. The district court apparently viewed the distinction between public-interest suits and purely private suits as the key standard for fee awards. The court of appeals focused instead on the necessity for fees as a stimulus to bringing suit; it seemed to view the mix of public and private interests in a particular suit mainly as a useful tool in assaying the likelihood that the private interest would suffice to spark litigation and attract competent counsel.

To illustrate the difference, consider an indigent plaintiff who sues under section 1983 to recover specific property wrongfully seized. He seeks no money damages, and his specific remedy is entirely personal. The district court's approach suggests that he recovers no fee because his action is private in nature. According to the appellate court's analysis, however, the plaintiff should recover fees because he will otherwise be unable to finance his suit. 
On the other hand, the court of appeals declined to accept the appellant's assertion of an essentially automatic entitlement to an award under the Newman-Northcross standard. The court reasoned that the Supreme Court's aim in both Newman and Northcross had been to encourage plaintiffs, through adequate incentives, to bring suits to enforce civil rights. So, in a case such as Newman, in which the plaintiff sought only injunctive relief, the recovery of the full costs of litigation-including attorney's fees-is necessary since there is no fund of damages from which those costs might be recovered. In contrast, in a case such as Zarcone, in which a plaintiff seeks damages and the potential recovery is large enough to attract private counsel on a contingent-fee basis, the concerns of Newman-Northcross are inapplicable. ${ }^{31}$ Instead, the court held, the focus should be on whether the plaintiff"s "prospects for a substantial monetary recovery" are "sufficiently bright." 32 That Zarcone's prospects were in fact sufficiently bright was demonstrated by the "clear wrongfulness of the challenged conduct," by the existence of easily demonstrable injuries, such as hospital costs, and by Zarcone's ability to engage an attorney on a contingent-fee basis. ${ }^{33}$

The court of appeals did not suggest, however, that the existence of bright prospects for the plaintiff in a noninjunctive suit automatically precludes the award of attorney's fees. Because of the particular "nature of the rights and interests at stake," award might be proper despite the presence of bright prospects. Thus, fee shifting may still be appropriate "when the claim involves civil rights of broad significance, prosecuted on behalf of a large class, and the prospective monetary award, if the suit is successful, would be modest in relation to the time, effort, and skill required of counsel."ss In addition, a suit involving no formal class or injunctive relief can merit a fee award if it is a "test case, involves legal issues of recurrent public importance, or is otherwise imbued with the public interest." "36 Zarcone's case, however, was

${ }^{31}$ Id. at 1044 ("[T]he principal factor . . . is whether a person in the plaintiff's position would have been deterred or inhibited from seeking to enforce civil rights without an assurance that his attorneys' fees would be paid if he were successful.").

\footnotetext{
${ }^{32}$ Id.

${ }^{33} \mathrm{Id}$.

34 Id.

${ }^{35} I d$.

${ }^{36} I d$. at n.6.
} 
found to involve an "essentially private injury." 37 Other factors mentioned by the court were:

the size of the benefits conferred by the suit on the public or on others, the amount of any fund created by the litigation (and its adequacy to cover the plaintiff's costs and compensate him for actual damages), the presence or absence of any bad faith or obdurate conduct on the part of either party, and any unjust hardship that a grant or denial of fee-shifting might impose. ${ }^{38}$

In Buxton v. Patel, ${ }^{39}$ the Ninth Circuit noted the apparent conflict between the First and Second Circuits. ${ }^{40}$ After quoting extensively from Sargeant and Zarcone, the court simply stated its conclusion that the latter's approach was preferable. ${ }^{41}$ It applied Zarcone's bright-prospects standard to affirm a denial of attorney's fees in a damage action brought under section 1982 of Title 42 for discrimination in the leasing of property. ${ }^{42}$

\section{Congressional Intent AND the Newman-Northcross STANDARD}

The Supreme Court's 1975 decision in Alyeska provided the impetus $^{43}$ for the enactment of the Civil Rights Attorney's Fees

${ }^{37}$ Id. at 1044 (footnote omitted).

${ }^{38}$ Id.

39 595 F.2d 1182 (9th Cir. 1979).

60 Id. at 1184-85. The Zarcone court did not cite or mention Sargeant, which was decided less than three months earlier.

11 Id. Buxton stands in contrast to Dennis v. Chang, 611 F.2d 1302 (9th Cir. 1980), in which a different panel of the same court rejected the defendants' contention that a fee award should be denied as unnecessary since the legal aid organization involved was already voluntarily providing free counsel in civil rights cases. That contention was contrary to the "broad and unequivocal" language of section 1988, id. at 1305, and contravened the statutory purpose of "encourag[ing] compliance with and enforcement of the civil rights laws," id. at 1306 (footnote omitted). The court also doubted the factual inference that an award was unnecessary, since fee awards would encourage the organization to continue its civil rights activity, id. at 1725 . See also text and note at note 61 infra.

The need for statutory fee awards to aid organizations that provide free counsel in civil rights cases, as found by the court in Dennis, would seem to be more acute than ever in light of the recent decision by the Ford Foundation to curtail its heretofore extensive financial support for such organizations. See Ford Foundation to Stop Aid to 'Public Interest' Law Firms, Washington Post, Sept. 14, 1979, § F, at 1, col. 1. See also Councll For Public INTEREST LAw, supra note 6, at 229 (graph showing that Ford Foundation was responsible for $52.7 \%$ of all foundation support for public interest law firms).

12595 F.2d at 1185 .

${ }^{43}$ Even before the decision, though, Congress had initiated hearings on the question of awarding attorney's fees in the overall context of financing public interest litigation. The 
Awards Act of $1976 .{ }^{44}$ In House hearings ${ }^{45}$ held shortly after the decision, witnesses testified that Alyeska had caused civil rights litigants to suffer "very severe hardships," that "[t]housands of dollars in fees were automatically lost in the immediate wake of the decision," and that "private lawyers were refusing to take certain types of civil rights cases because the civil rights bar, already short of resources, could not afford to do so."46 The House Report concluded that this testimony had demonstrated a "compelling need" for legislation. ${ }^{47}$

The result was an amendment to section 1988 of Title 42, empowering district courts to award attorney's fees to prevailing parties in suits brought under certain listed civil rights statutes. ${ }^{48}$ The text of section 1988 gives no guidelines to a court exercising that discretion; a literal reading could lead to the conclusion that the trial judge is free to use his discretion as he sees fit. An examination of the House and Senate Reports ${ }^{49}$ accompanying the bill demonstrates, however, that the Fifth Circuit was correct in finding that section 1988 "means more than it appears to say." It is clear from these documents that Congress intended that the Newman-Northcross standard be applied to all cases in which prevailing plaintiffs seek attorney's fees under section 1988.

The congressional purpose in amending section 1988 was far from innovative. Consonant with its purposes of "remedy[ing] the anomalous gaps in our civil rights law" created by Alyeska and of achieving "consistency"52 and "uniformity"53 in that field, Congress aimed simply to extend the attorney's fee standard of mod-

Effect of Legal Fees on the Adequacy of Representation: Hearings Before the Subcomm. on Representation of Citizen Interests of the Senate Comm. on the Judiciary, 93d Cong., 1st Sess. (1973).

4 Pub. L. No. 94-559, 90 Stat. 2641 (1976) (codified at 42 U.S.C. $\$ 1988$ (1976)).

15 Awarding of Attorney's Fees: Hearings on H.R. 9552 Before the Subcomm. on Courts, Civil Liberties, and the Administration of Justice of the House Comm. on the Judiciary, 94th Cong., 1st Sess. (1975).

${ }^{46}$ H.R. REP. No. 1558, 94th Cong., 2d Sess. 2-3 (1976) [hereinafter cited as House REPORT].

47 Id. at 3.

442 U.S.C. $\$ 1988$ (1976). For the text of the Act, see note 9 supra.

49 House RePort, supra note 46; S. REP. No. 1011, 94th Cong., 2d Sess. (1976) [hereinafter cited as Senate REport], reprinted in [1976] U.S. Code Cong. \& AD. News 5908.

so Concerned Democrats v. Reno, 601 F.2d 891, 892 (5th Cir. 1979) (per curiam).

${ }^{31}$ Senate Report, supra note 49 , at 1,4 , reprinted in [1976] U.S. Code Cong. \& AD. News 5908, 5909, 5911 .

${ }^{32}$ Id. at 1, reprinted in [1976] U.S. CODE CoNG. \& AD. NEWS at 5909.

${ }^{53}$ House RePoRT, supra note 46 , at 1 . 
ern civil rights acts to suits under older statutes as well. The relevant language in section 1988 was taken verbatim from analogous provisions in the Civil Rights Act of 1964 and similar laws. ${ }^{54}$ The House Report stated that since "other statutes follow this approach, the courts are familiar with these terms [of the bill] and in fact have reviewed, examined, and interpreted them at some length."'ss

Congress intended that the established standard (NewmanNorthcross) be applied under section 1988. The Senate Report said so expressly:

It is intended that the standards for awarding fees be generally the same as under the fee provisions of the 1964 Civil Rights Act. A party seeking to enforce the rights protected by the statutes covered by $\mathrm{S}$. 2278, if successful, "should ordinarily recover an attorney's fee unless special circumstances would render such an award unjust."ss

The House Report was less direct but equally unequivocal, stating that, "at a minimum," the courts should construe the new Act according to "existing judicial standards, to which ample reference is made in this report."

64 Voting Rights Act Amendments of 1975, § 402, 42 U.S.C. $\S 1973(1)(e)$ (1976); Civil Rights Act of 1964, § 204(b), 42 U.S.C. $\S 2000 \mathrm{a}-3$ (b) (1976); id. § $706(\mathrm{k}), 42$ U.S.C. $\S 2000 \mathrm{e}-$ 5(k) (1976). See House REPORT, supra note 46, at 5-6.

Section 1988, and the statutes on which it was modeled, contrast with section 812 (c) of the Fair Housing Act of 1968,42 U.S.C. $\$ 3612$ (c) (1976), which expressly limits fee awards to plaintiffs who "in the opinion of the court [are] not financially able to assume said attorney's fees." See also Fort v. White, 530 F.2d 1113, 1117-18 (2d Cir. 1976). If, as the Zarcone and Buxton courts suggest, Congress intended to authorize fee awards under section 1988 only in cases in which they were "necessary" to enable the plaintiffs to sue, it certainly would have done better to model its statute on the Fair Housing Act provision than on the statutes whose relevant wording it did use. See Hughes v. Repko, 578 F.2d 483, 488 (3d Cir. 1978) (refusing to read section 1988, as applied to case brought under 42 U.S.C. $\S 1982$ (1976), in pari materia with Fair Housing Act provision).

${ }^{55}$ House Report, supra note 46 , at 6.

s8 Senate RePort, supra note 49 , at 4 (quoting Newman, 390 U.S. at 402), reprinted in [1976] U.S. Code Cong. \& Ad. News 5908, 5912. Accord, 122 Cong. Rec. 35128 (1976) (remarks of Rep. Seiberling):

[T] he civil rights attorneys' fee legislation [predecessor to bill that ultimately amended section 1988] which I introduced . . . called for the mandatory award of attorneys' fees to prevailing plaintiffs, because I felt that the awards should be automatic except in the most extraordinary circumstances. I understand that S. 2278 will codify that view as to prevailing plaintiffs, following the Piggie Park guidelines.

${ }_{57}$ House REPORT, supra note 46 , at 8 . The Report at first suggested that the bill would grant broad discretion, contrasting the more drastic possibility of mandatory awards with its own "more moderate approach" of leaving the issue to judicial discretion. Id. Any ambiguity 
vailing plaintiff's entitlement to fees was the committee's cursory citation and description of the Newman and Northcross holdings. ${ }^{58}$ Nowhere did either committee suggest that some other standard might govern plaintiffs' awards in some subset of section 1988 cases. ${ }^{59}$ On the contrary, the House Report stated that recovery of damages should not preclude a fee award, remarking that civil rights plaintiffs should be treated as favorably as antitrust plaintiffs, who can recover both treble damages and attorney's fees. ${ }^{60}$ Moreover, the Report stated that a prevailing party represented by a legal services organization is entitled to fees, ${ }^{61}$ suggesting that inability to attract counsel is no prerequisite to recovery of fees.

Even if Congress had been less explicit about what standard was intended, there could have been little doubt about the state of the case law on which it relied. Both Newman and Northcross did arise in legal contexts in which no damage claim would lie, ${ }^{62}$ and the Court did refer to the need for fees as a stimulus to injunctive suits. ${ }^{63}$ Nevertheless, by 1976 , Newman-Northcross had become the accepted standard for plaintiffs' fee awards in civil rights cases subject to textually identical fee provisions, with no mention of any distinction between injunctive and damage actions, or of any special rule for damage actions involving "bright prospects" of recovery for the claimant. ${ }^{64}$

thus raised, however, was cleared up by the additional statement that exercise of that discretion would be "guided of course by the case law interpreting similar attorney's fee provisions." Id.

${ }^{58}$ Id. at 6.

s9 Both Reports, however, stated that under section 1988, as under its predecessors, awards of fees to defendants were governed by a different and decidedly more restrictive standard. Such awards are proper only where a suit is "clearly frivolous, vexatious, or brought.for harassment purposes." SENATE REPORT, supra note 49, at 5, reprinted in [1976] U.S. Code Cong. \& Ad. News 5908, 5912. Accord, House Report, supra note 46, at 6-7. See, e.g., United States Steel Corp. v. United States, 519 F.2d 359 (3d Cir. 1975). See also Christiansburg Garment Co. v. EEOC, 434 U.S. 412 (1978).

${ }^{60}$ House RePort, supra note 46, at 8-9. See also text and notes at notes 88-94 infra.

${ }^{61}$ House Report, supra note 46, at 8 n.16. See Dennis v. Chang, 611 F.2d 1302 (9th Cir. 1980).

${ }_{62}$ Newman was brought under Title II of the Civil Rights Act of 1964, 42 U.S.C. $\S 2000$ a-3(a) (1976), which does not provide for recovery of damages; Northcross was a school-desegregation suit.

${ }^{63}$ Newman, 390 U.S. at 402; Northcross, 412 U.S. at 428.

${ }^{64}$ In several single-plaintiff cases, courts have awarded attorney's fees under Title VII, despite the presence of substantial back pay damage awards, without adverting to the relevance or irrelevance of damages to fee awards. Kaplan v. International Alliance of Theatrical \& Stage Employees, 525 F.2d 1354 (9th Cir. 1975); Singer v. Mahoning County Bd. of Mental Retardation, 519 F.2d 748 (6th Cir. 1975) (per curiam); Muller v. United States Steel Corp., 509 F.2d 923 (10th Cir. 1975); Schaeffer v. San Diego Yellow Cabs, Inc., 462 
Both the district court and the court of appeals in Zarcone, in formulating their tests for fee awards in damage actions, relied to some extent upon the importance of the particular action as an instrument of enforcing social policy. ${ }^{65}$ Such line drawing within the field of cases covered by section 1988 conflicts with indications in the legislative history that the proper boundary between important and unimportant suits was the one drawn by the Act itself. The Senate Committee noted that the holding in Alyeska was that "only Congress, and not the courts, could specify which laws were important enough to merit fee shifting under the "private attorney general' theory." ${ }^{66}$ Nevertheless, Congress chose to limit its response to the civil rights field, even though Alyeska affected suits in a wide range of subject areas. ${ }^{67}$ The civil rights statutes were characterized as embodying "important Congressional policies," protecting "fundamental rights," 68 and calling for "the broadest and most effective remedies available . . . ."70 Attorney's fees have traditionally been regarded as appropriate in this field. ${ }^{71}$ In short, it appears that Congress intended that fees be recoverable in all suits brought under the statutes listed in section 1988-not because of the number of persons affected, but because of the nature of the substantive rights they protect.

F.2d 1002 (9th Cir. 1972); Smith v. Fletcher, 393 F. Supp. 1366 (S.D. Tex. 1975), modified on other grounds, 559 F.2d 1014 (5th Cir. 1977); Tidwell v. American Oil Co., 332 F. Supp. 424 (D. Utah 1971). The question has arisen in only one case. In Chastang v. Flynn \& Emrich Co., 381 F. Supp. 1348 (D. Md. 1974), the district court denied attorney's fees, resting in part on an argument (much like that made in Zarcone) that a fee award was unnecessary in light of the plaintiffs' substantial money recovery. Id. at 1350-51 (alternative ground). The court of appeals, while affirming the denial on other grounds, concluded that the Newman-Northcross standard applied to the case. 541 F.2d 1040, 1044-45 (4th Cir. 1976) (dictum). See also Christiansburg Garment Co. v. EEOC, 434 U.S. 412, 417 (1978) (dictum) (remarking in broad language that Newman-Northcross applies equally to Title VII actions).

${ }^{65} 438$ F. Supp. at 790-92; 581 F.2d at 1044. See text and notes at notes $25-28,34-37$ supra.

a Senate Report, supra note 49, at 4, reprinted in [1976] U.S. Code Cong. \& Ad. News 5908, 5911. See Alyeska, 421 U.S. at 260-64, 269-71.

${ }^{87}$ House REPORT, supra note 46, at 2. Alyeska itself was an environmental case.

88 Senate Report, supra note 49, at 2, reprinted in [1976] U.S. Code Cong. \& AD. NEwS 5908, 5910.

${ }^{69}$ Id. at 5, reprinted in [1976] U.S. Cone Cong. \& AD. News at 5912. See id. at 2, reprinted in [1976] U.S. CODE CoNG. \& AD. NEws at 5910 ("fundamental laws"); House REPORT, supra note 46, at 2 (" "policy . . . of the highest importance" ") (quoting Newman, 390 U.S. at 402); id. at 6 ("important rights").

30 Senate Report, supra note 49 , at 3 , reprinted in [1976] U.S. Code Cong. \& Ad. News 5908, 5910.

${ }^{71}$ Id. at 3, 4, reprinted in [1976] U.S. Code Cong. \& Ad. News at 5910, 5912. 


\section{Bright Prospects and Congress's Policy Concerns}

As the Committee Reports show, underlying the enactment of the attorney's fee provisions of section 1988 was Congress's primary concern, after Alyeska, that violations of some civil rights statutes might go unredressed and unpunished. ${ }^{22}$ Fee shifting would reduce the likelihood of such a result. First, by providing a source of attorney compensation, section 1988 makes litigation a realistic possibility for many injured persons of modest means who otherwise would be unable or unwilling to bear the expense of a successful complaint-especially when nonpecuniary rights or remedies are involved. Second, by charging to the defendant the attorney's fees of the successful plaintiff, the statute deters the former from raising unmeritorious defenses or otherwise using obstructive litigation tactics that might increase the legal fees. Third, a provision for fee awards serves to deter the violation giving rise to the cause of action by increasing the defendant's exposure to liability.

The bright-prospects standard adopted by the Zarcone and Buxton courts, if correctly understood and applied, is an adequate solution to the problem of stimulating the bringing of suits. Indeed, the standard tends to assume that financial inability to sue is the sole reason for attorney's fee provisions. ${ }^{73}$ The bright-prospects rule, however, deals only imperfectly with bad-faith defensive litigation and entirely ignores the general-deterrence effect.

\section{A. Opening the Courts to Civil Rights Plaintiffs}

One of Congress's motivating concerns in amending section 1988 to allow fee awards was to insure the ability of individuals to sue for violations of their civil rights. Civil rights statutes, as both House and Senate Committees noted, depend largely on private litigation for their enforcement. ${ }^{74}$ The majority of civil rights plain-

72 "If private citizens are to be able to assert their civil rights, and if those who violate the Nation's fundamental laws are not to proceed with impunity, then citizens must have the opportunity to recover what it costs them to vindicate these rights in court." Id. at 2, reprinted in [1976] U.S. Code CoNG. \& AD. News at 5910. See id. at 2-3, 4, 6, reprinted in [1976] U.S. Code Cong. \& AD. News at 5910, 5911-12, 5913; House Report, supra note 46, at 2-3.

${ }^{73}$ In Dennis v. Chang, 611 F.2d 1302 (9th Cir. 1980), in an analogous context, the same court that decided Buxton seemed to treat the fact that the plaintiffs actually obtained free legal aid as irrelevant to fee entitlement, $i d$. at $1304 \&$ n.4, 1305, and rejected the defendant's argument that fees should be denied because they were unnecessary to encourage the plaintiffs' counsel to continue to litigate such cases, $i d$. at 1304-06. See note 41 supra.

74 House Report, supra note 46, at 1; Senate Report, supra note 49, at 2,6, reprinted 
tiffs, though, are financially unable to hire legal counsel. ${ }^{75}$ The problem is especially acute in cases in which only injunctive relief is sought. ${ }^{78}$ Without fee awards, Congress's civil rights policies might become "hollow pronouncements";7 many citizens could not vindicate their rights, and many wrongdoers could violate the laws with impunity. ${ }^{78}$

The Zarcone-Buxton bright-prospects standard, at least in theory, provides adequate inducement for plaintiffs to bring meritorious complaints. It remains unclear, however, whether in practice the courts could convincingly distinguish cases that evince bright prospects from those that do not. Unless the courts make it their practice to err on the side of generosity to plaintiffs, some plaintiffs will be discouraged from bringing suit: some plaintiffs (or their lawyers), who might have been willing to bring a complaint under a Newman-Northcross regime, might be deterred by a fear that the prospects of success will appear brighter to the court in hindsight than they estimate them to be. ${ }^{79}$ Nevertheless, in the vast majority of cases, the bright-prospects standard will operate, as it was designed to do, to deny fees only in those cases in which the private incentives are sufficient to ensure that plaintiffs can secure adequate representation. ${ }^{80}$

in [1976] U.S. Code Cong. \& Ad. News 5908, 5910, 5913.

${ }^{75}$ HOUSE REPORT, supra note 46 , at 1,6; SENATE REPORT, supra note 49 , at 2 , reprinted in [1976] U.S. Code Cong. \& AD. News 5908, 5910.

${ }^{76}$ The House Report also noted that immunity doctrines and special defenses available to public officials will preclude damages in many civil rights cases. House REPORT, supra note 46 , at 9 . But cf. id. at 8-9 (damages no bar to fee recovery).

77 Senate Report, supra note 49, at 6, reprinted in [1976] U.S. Code Cong. \& Ad. News 5908, 5913. See id. at 3, reprinted in [1976] U.S. Code Cong. \& Ad. News. 5908, 5910; House REPORT, supra note 46 , at 1 .

7 Senate Report, supra note 49 , at 2,6 , reprinted in [1976] U.S. Code Cong. \& AD. News 5908, 5910, 5913; House REPORT, supra note 46, at 1, 2-3.

${ }^{78}$ In a typical case, in which the amount of damages (if any) is known to be reasonably large but liability is contested, the Zarcone standard poses no real problem. Either the plaintiff will recover his damages (yielding the contingent fee to the lawyer), or he will win an injunction but lose on damages (in which case the court will award a fee under section 1988), or he will lose entirely (in which case the lawyer would not be entitled to a fee even under Newman-Northcross). A damage claim of uncertain amount, however, might be appended to a strong and important injunctive case. If the result is a moderate damage award, the contingency share may be less than the lawyer's expectations would have been under Newman-Northcross, yet still enough to satisfy a trial judge that bright prospects existed.

so The bright-prospects standard may have some marginal effect in discouraging contingent-fee arrangements, however. Given the nature of the bright-prospects test (and the result in both Zarcone and Buxton), it seems likely that, despite the Buxton court's assurance to the contrary, $595 \mathrm{~F} .2 \mathrm{~d}$ at $1185 \mathrm{n} .3$, a plaintiff's ability to retain a lawyer on a contingent-fee basis will be taken as at least prima facie evidence of bright prospects, and will 


\section{B. Obstructive Litigation by Defendants}

Awarding attorney's fees serves generally to deter the raising of untenable defenses or other bad-faith litigational conduct by defendants. ${ }^{81}$ The Supreme Court, in Newman, recognized this as a purpose behind the civil rights fee provisions on which section 1988 was modeled; ${ }^{82}$ indeed, it relied on the presence of bad faith in that case to uphold its finding that no special circumstances existed to prevent an award. ${ }^{83}$

This consideration is expressly addressed in the bright-prospects standard. Even where bright prospects exist, said the Zarcone court, fee awards might sometimes be appropriate, and one of the relevant factors in that determination is "the presence or absence of any bad faith or obdurate conduct on the part of either party." 84

Since there was no finding of bad-faith conduct in either Zarcone $^{85}$ or Buxton, ${ }^{86}$ neither court had occasion to delineate the importance of the factor in more detail. If courts following Zarcone treat bad-faith conduct as only one factor among several in a general balancing test, then bad faith might be overlooked in some cases because of other considerations, with a consequent impair-

therefore tend to disqualify such plaintiffs from fee awards more or less automatically.

It is not clear, though, that this phenomenon will necessarily decrease significantly the availability of counsel for civil rights plaintiffs. An attorney who wishes to prosecute a civil rights complaint on behalf of an indigent client is not obliged to take it on a contingent-fee basis; he may charge the client nothing and hope to win a fee award from his opponent. Legal aid organizations, for example, will often do this. See generally Dennis v. Chang, 611 F.2d 1302 (9th Cir. 1980); Note, Awards of Attorney's Fees to Legal Aid Offices, 87 Harv. L. Rev. 411 (1973). Even if the case has bright prospects for a monetary recovery, it seems unlikely that a court would deny a fee award on Zarcone grounds when counsel has so transparently relied on it. Relying on a fee award is itself a contingent arrangement, since only a prevailing party can recover; the main difference between the two methods of compensation is not so much when they will pay off as how much. The profit-seeking attorney, therefore, will choose his mode of compensation by comparing expected costs (the basis of a fee-award recovery) with the expected judgment (the basis of a contingent fee). Regardless how the balance comes out, he will not refuse the case unless he thinks neither mode of compensation is likely to reward his efforts sufficiently -and in such a situation he would not have taken the case even under a Newman-Northcross regime. So while the Zarcone standard may decrease the incidence of contingent-fee arrangements (by deterring attorneys from following both alternatives simultaneously), it will probably have little effect on the number of cases brought.

${ }^{81}$ See note 2 supra.

82390 U.S. at 402.

${ }^{83}$ Id. at $402-03$ n.5.

8451 F.2d at 1044.

ss Id. at 1044-45.

${ }^{86} 595$ F.2d at 1185 . 
ment of effective deterrence. It seems more likely, however, that the mere presence of bad faith (at least above some threshold level) would trigger an award of attorney's fees more or less automatically.

One can argue that the best way to deter such bad-faith conduct is indeed to assess fees when it is present and to deny fees when it is not. Yet, any standard that establishes bad faith as a demarcation between the recovery and nonrecovery of fees invites, or at least tends to overlook, marginal tactics. ${ }^{87}$ Under an acrossthe-board rule such as Newman-Northcross, by contrast, the prospect of attorney's fees serves to deter undesirable conduct at all levels. The more bad-faith defenses or troublesome tactics a defendant employs, the greater will be the plaintiff's fee he will ultimately have to pay. In short, it is likely that while the bright-prospects standard will serve to deter serious defense misconduct, it will not be as effective a deterrent as the Newman-Northcross standard.

\section{Deterrence of Civil Rights Violations}

The policy considerations discussed above have concerned the general problem of obtaining adequate redress when a civil rights violation occurs-first, by assuring that the injured party is able to sue, and second, by preventing the violator from using improper litigation tactics to obstruct vindication of the plaintiff's rights. A provision for attorney's fees, however, can also help deter violations giving rise to the litigation. By adding to the total amount that the violator will have to pay to a successful plaintiff, the prospect of a fee award may increase deterrence of the forbidden conduct at the outset.

The Supreme Court has recognized and approved this general deterrent effect as a useful purpose of section $1988 .^{88}$ In Carey $v$.

${ }^{87}$ Indeed, the Supreme Court, in the context of fee awards to defendants, has expressly cautioned the courts not to apply the bad-faith standard in too draconian a fashion: "[I]t is important that a district court resist the understandable temptation to engage in post-hoc reasoning by concluding that, because a plaintiff did not ultimately prevail, his action must have been unreasonable or without foundation. This kind of hindsight logic could discourage all but the most airtight claims . . . " Christiansburg Garment Co. v. EEOC, 434 U.S. 412, 421-22 (1978).

${ }^{88}$ Although the Committee Reports do not directly discuss the usefulness of fee awards as a deterrent device in themselves, see also note 93 infra, they leave no doubt that Congress was as concerned with obtaining compliance with the civil rights laws in the first instance as with assuring a just remedy for victims of violations after the fact. Thus, for example, one of the primary reasons given for Congress's desire to enable indigent plaintiffs to 
Piphus, ${ }^{80}$ two students had sued under section 1983 for deprivations of procedural due process in their suspensions from high school. Although the Court held that the plaintiffs could recover only nominal damages for the violations of their rights in the absence of proof of actual harm, it carefully left open the question whether exemplary punitive damages might be imposed in proper cases for a deterrent purpose. ${ }^{90}$ Moreover, the Court noted, "the potential liability of $\S 1983$ defendants for attorney's fees [under section 1988] provides additional-and by no means inconsequential-assurance that agents of the State will not deliberately ignore due process rights."91

The bright-prospects standard ignores this consideration entirely. The object of deterring civil rights violations in society is a public one, not directly related to the just remedy due to the victim of a violation already committed. The deterrence policy applies with equal force to all civil rights cases-with or without bright prospects. Yet it might be argued that where a large damage judgment is assessed, there is no need for attorney's fees as an additional deterrent. This argument overlooks the nature of deterrent remedies; the proper question is not one of necessity but of degree. There are several aspects of a civil rights suit that might deter a potential violator from unlawful conduct. One is the prospect of having to pay damages. Another is the cost of defending a suit, whether it seeks monetary or injunctive relief. A third is the negative publicity resulting from being labeled a wrongdoer. The prospect of having to pay the victim's litigation costs simply imposes another element of penalty for the unlawful conduct. In simple terms, whatever other deterrent devices may already operate in a given case, the total level of deterrence will always be greater if attorney's fees are to be assessed than if they are not.

The reasoning above does not compel the use of fee awards as deterrent devices. Rather, the reasoning suggests that the presence or absence of bright prospects for recovery of damages is not rele-

sue was the likelihood that without the actions of "private attorneys general," the civil rights laws could become dead letters in practice. House REPORT, supra note 46, at 1; SENATE RePorT, supra note 49, at 2,3,6, reprinted in [1976] U.S. Code Cong. \& Ad. News $5908,5910,5913$.

so 435 U.S. 247 (1978).

so Id. at 257 n.11. The Court noted that the case presented no basis for a punitive award.

${ }^{91}$ Id. Continuing, the Court cited the "criminal counterpart of $\S 1983$," 18 U.S.C. $\S 242$ (1976). Accord, Dennis v. Chang, 611 F.2d 1302, 1306 (9th Cir. 1980). 
vant to the usefulness of attorney's fees as a deterrent device. On the contrary, to the extent that damages and fees are viewed as alternative remedies, they undermine each other's deterrent value. If a civil rights violator knows that his conduct is likely to make him liable for substantial damages, and that a fund of damages will be regarded by the court as the proper source of the plaintiff's litigation expenses, he will quite correctly disregard the prospect of a fee assessment. ${ }^{92}$

The paradox inherent in this result becomes even more distinct if part or all of the damage award is punitive or exemplary. ${ }^{93}$ While the prospect of compensatory damages may have a salutary effect on a potential defendant's propensity to violate the civil rights laws, their primary purpose is to compensate the plaintiff rather than to punish the defendant. Punitive damages, by contrast, are assessed solely for their deterrent value. If, under the bright-prospects standard, an award of punitive damages in addition to an award of compensatory damages precludes the plaintiff from recovering, for example, attorney's fees of $\$ 10,000$, the first $\$ 10,000$ of the punitive damages award is a nullity as far as the defendant is concerned. In the absence of punitive damages, the $\$ 10,000$ fee would have been awarded. The bright-prospects standard thus stands as a major obstacle to a jury's ability to fit its verdict to its assessment of the defendant's blameworthiness and the need for deterrence. ${ }^{94}$

${ }^{82}$ Cf. Kalven, The Jury, the Law and the Personal Injury Damage Award, 19 Оноо Sr. L.J. 158, 176-78 (1958) (discussing the possibility that damage verdicts may hide awards of attorney's fees, and concluding that since a verdict is a composite and compromise of all jurors' views, it is not a simple yes-or-no question).

${ }^{83}$ Although its opinion is elliptical on the point, the Zarcone court appears to have suggested that an award of punitive damages would weigh against an award of attorney's fees. One of its listed factors is the "adequacy [of the fund created by the litigation] to cover the plaintiffs' costs and compensate him [sic] for actual damages," 581 F.2d at 1044 (emphasis added); further, the court referred to the punitive award of $\$ 61,000$ in reaching its conclusion that denial of fees was appropriate, $i d$. Such an implication makes sense in the context of the Zarcone court's single-minded concern for enabling indigent plaintiffs to sue, since the prospect of punitive damages can only help a plaintiff's chances of hiring an attorney on a contingent fee. Nevertheless, as shown in text, such a consideration is improper in light of its adverse effect on deterrence.

94 This line of reasoning is implicitly ratified in the legislative history. The House Report, discussing the relevance of damages to fee awards, noted that "[u]nder the antitrust laws, for example, a plaintiff may recover treble damages and still the court is required to award attorney fees. The same principle should apply here as civil rights plaintiffs should not be singled out for different and less favorable treatment." House REPORT, supra note 46, at 8-9. The House, at least, meant to approve the assessment of fees on top of a punitive, windfall recovery. The Senate Report did not address the question, but it contains nothing 


\section{CONCLUSION}

The bright-prospects standard espoused by the Zarcone and Buxton courts contains several defects. The most serious is simply that the application of a different, and more difficult, standard of fee entitlement to plaintiffs who recover damages than to other civil rights plaintiffs is contrary to Congress's intention to apply the established Newman-Northcross standard to all cases arising under section 1988. Moreover, the bright-prospects standard does not adequately serve all of the policies embodied in the Act. In particular, it ignores the usefulness of fee awards as a deterrent to civil rights violations, and it deals only imperfectly with the problem of bad-faith litigation tactics by defendants.

The proper standard for awards of attorney's fees to prevailing plaintiffs under section 1988 is thus the same regardless of the nature of the remedy sought or likely to be won: the practically mandatory standard of Newman-Northcross. This conclusion does not read judicial discretion entirely out of the statute. Discretion is still properly exercised for a host of reasons unrelated to whether the action is one for damages or an injunction. ${ }^{95}$ Moreover, an exercise of discretion is built into the "special circumstances" exception to the Newman-Northcross standard.$^{96}$ All that is argued here is that under section 1988 a court does not have the discretion to ignore the Newman-Northcross rule and deny fees on the ground that a plaintiff had bright prospects of recovering a monetary judgment.

Michael Buckley

to the contrary.

os Judicial discretion may still be properly exercised under section 1988 in cases in which a prevailing defendant seeks a fee award, see note 59 supra; in which a plaintiff prevails on some but not all issues, see, e.g., cases collected in Lipson, supra note 15, at 259 n.105; in which the case is settled in such a fashion as to obscure who "prevailed", see, e.g., House REPORT, supra note 46, at 7; SENATE REPORT, supra note 49, at 5, reprinted in [1976] U.S. Code Cong. \& Ad. News 5908, 5912-13; in which the plaintiff seeks an award pendente lite, see, e.g., House REPORT, supra note 46, at 9; SENATE RePorT, supra note 49, at 5, reprinted in [1976] U.S. CodE CONG. \& AD. NEWS 5908, 5912; or in which the defendant simply abandons the challenged practice prior to a judgment against him, see, e.g., HousE REPORT, supra note 46 , at 7 .

${ }^{86}$ See note 16 supra. 